\title{
Foreign language reading strategy use of intermediate level adult Turkish EFL learners
}

\author{
Fatma Aydin \\ f.aksoy@anadolu.edu.tr \\ Anadolu University \\ School of Foreign Languages, Eskisehir, Turkey \\ Ozgur Yildirim \\ oyildirim@anadolu.edu.tr \\ Anadolu University \\ Faculty of Education, Eskisehir, Turkey
}

Received: July 28, 2017; $\quad$ Accepted: September 8, 2017; Published: September 30, 2017

\begin{abstract}
The purpose of this study was to investigate foreign language reading strategy use of a group of intermediate level adult Turkish EFL learners. The participants of the study were 87 Turkish first-year university students who were taking intermediate level English courses at a state university in Turkey. The main instrument of the study was a reading strategies survey which consisted of 30 items with three sub-scales: global or metacognitive reading strategies, problem-solving or cognitive reading strategies, and support reading strategies. Semi-structured interviews were also conducted to support the quantitative data. The quantitative data were analyzed using descriptive statistics (mean, standard deviation, frequencies, percentages) and one-way ANOVA with repeated measures. As for the analysis of the qualitative data, tape-recorded interviews were first transcribed and then analyzed by grouping each interviewee's response according to the sub-scales of the survey. Results of the study indicated that intermediate-level adult Turkish EFL learners show the moderate overall use of reading strategies; problem-solving strategies are the most favored strategies, and they are followed by global reading strategies and supplementary reading strategies.
\end{abstract}

Keywords: foreign language, reading strategies, EFL, adult learners 
How to cite this paper: Aydin, F., \& Ozgur Yildirim, O. (2017). Foreign language reading strategy use of intermediate level adult Turkish EFL learners. Journal on English as a Foreign Language, 7(2), 135-158.

There are a variety of purposes for reading in a second or foreign language. Grabe and Stoller (2002) list the purposes for reading as searching for simple information, skimming quickly, learning from texts, integrating information, reading to write or searching for information required for writing, reading to critique, and reading for general comprehension. Hedge (2000), on the other hand, mentions receptive reading, reflective reading, skim reading, scanning and intensive reading. Receptive reading refers to reading to enjoy oneself or understand the main points. Reflective reading means reading for some time and pausing to reflect on what is read. Skim reading is useful for getting an overall idea of the text, whereas scanning is searching the text quickly to find out specific information or details. Intensive reading, lastly, involves scrutinizing a text carefully.

Different purposes for reading require different skills and strategies. Grabe and Stoller (2002) point out that skills and strategies are two common terms that are involved in the fluent reading activity. Skills are automatic information-processing techniques that are applied unconsciously. They may be either at the level of grapheme-phoneme correspondence or at the level of making a summary of the text (Paris, Wasik, \& Turner, 1991). Strategies, on the other hand, refer to deliberate actions that readers take to achieve certain goals while reading. In this sense, a skill might be a strategy once it is used on purpose. By the same token, strategies might turn into skills when they begin to be applied automatically, which increase their efficiency (Paris et al., 1991).

In addition to involving skills and strategies, fluent reading comprehension is a rapid, efficient and interactive process. Hedge (2000) states that reading's being interactive can be explained in two ways. First, the readers establish a dynamic relationship with the text in order to make sense of it. As readers become involved in reading, they combine their background knowledge with the knowledge from the text, which makes reading look like a dialogue between the reader and the text/author. It is worth making a note that readers make use of at least six types of knowledge to accomplish this interactive process: syntactic knowledge, morphological knowledge, general world knowledge, sociocultural knowledge, topic knowledge, and genre knowledge. The interplay among these various types of knowledge that readers benefit from to make sense of a text represents the second interpretation of reading's being interactive (Hedge, 2000). 
All in all, reading in a second or foreign language is a multivariate skill that combines and integrates a variety of cognitive, linguistic and non-linguistic skills rather than a single-factor process (Nassaji, 2003). These skills involve the very basic low-level processing abilities employed in decoding print and encoding visual configurations as well as high-level skills of syntax, semantics and discourse, and higher-level knowledge of text representation and integration of ideas with the reader's global knowledge (Nassaji, 2003).

Koda (2005) indicates that there are a number of essential components of reading: word recognition, vocabulary knowledge, intra-word awareness and word knowledge, information integration in sentence processing, discourse processing, and text structure. Besides, Jeon and Yamashita (2014), in a metaanalysis on L2 reading comprehension and its correlates, investigate ten key reading component variables. These are four high-evidence correlates, namely L2 decoding, L2 vocabulary knowledge, L2 grammar knowledge, L1 reading comprehension, and six low-evidence correlates, namely L2 phonological awareness, L2 orthographic awareness, L2 morphological awareness, L2 listening comprehension, working memory, and metacognition. Additionally, a good number of both L1 and L2 reading researchers accept that effective reading strategy use supports reading comprehension (Phakiti, 2003; Guthrie \& Taboada, 2004; Block \& Pressley, 2007; Hudson, 2007; Grabe, 2009; Akkakoson, 2013; Qanwal \& Karim, 2014; Peng, Siriyothin \& Lian, 2014).

Effective reading strategy use is one of the components that make a good reader. Therefore, a list of the factors that contribute to reading comprehension would be incomplete without reading strategy use. Grabe (2009) defines strategic reader as "one who automatically and routinely applies combinations of effective and appropriate strategies depending on reader goals, reading tasks and strategic processing abilities" (pp. 220). Becoming a strategic reader is essential in the sense that such a reader checks reading goals, evaluates hisher comprehension effectiveness and is able to better understand difficult texts applying appropriate strategies.

Multiple research studies have empirically supported a number of specific comprehension strategies. As a result of the significant differences found between experimental and control groups in these research studies, it is noted that effective strategy use boosts reading comprehension. Prior to mentioning some of these studies, it is first necessary to look through the effective reading strategies that have been recognized as offering the strongest help to reading comprehension according to research findings (Grabe, 2009). To begin with, summarizing has been found to lead to significantly better comprehension among readers. It is reported to help learners remember more information from a reading text. Second, forming questions is another 
important strategy, which improves memory regarding the information about the text, enables learners to better understand main ideas and increases the likelihood of accuracy in answering comprehension questions. Third, answering questions and elaborative interrogation, which simply refer to comprehension questioning, are useful for better text recall, inference making, and coherence building. Four, activating prior knowledge is also one of the strategies that give way to better comprehension of a text. However, it is worth mentioning that activating prior knowledge that is incompatible with information in the text might be dangerous for text comprehension. Therefore, teachers should pay attention to this hazardous effect of prior knowledge activation and learners should be guided accordingly. Another reading strategy is monitoring comprehension, which is rather an umbrella term, as it involves a number of minor strategies such as having a reason for reading and being aware of it, recognizing text structure, identifying main ideas, linking the text to background knowledge, relating reading goals to the text, becoming aware of the text difficulties and clarifying misunderstandings. The sixth reading strategy to mention is using text structure awareness. It involves becoming aware of and paying attention to a variety of systems that give information about the discourse structure of a text. Grabe (2009) lists these discoursesignaling systems as importance levels of information in texts, headings and subheadings, paragraphing choices, co-referential connections, relations of information, transition forms and signal words, patterns to organize text information such as for cause and effect, problem and solution, comparison and contrast. Reading comprehension also benefits from using graphic organizers such as Venn diagrams and flow charts, which help learners comprehend text structure, notice main ideas and recognize their relations to supporting ideas. Finally, inferencing plays a crucial role in coherence building. It is dependent on other processing skills and strategies such as prior knowledge, vocabulary knowledge, text structure awareness and comprehension monitoring.

As Qanwal and Karim (2014) indicate, reading strategies have been classified in divergent ways. According to some researchers (Pressley \& Wharton-McDonald, 1997; Qanwal \& Karim, 2014; Rice, 2009), for example, reading strategies fall into three categories as before-reading, while-reading, and post-reading strategies. Zhang (1993) offers a more comprehensive classification of reading strategies. These are cognitive strategies, compensation strategies, memory strategies and test-taking strategies. Cognitive strategies consist of prior knowledge activation, previewing, prediction and selfquestioning. Compensation strategies include vocabulary identification, drawing inferences and making connections. Memory strategies refer to visualizing, determining importance, skimming, scanning, summarizing, 
synthesizing information and evaluating. Lastly, test-taking strategies involve becoming aware of question types in reading tests and corresponding questionanswering strategies.

All in all, according to Grabe (2009, p.228), good L2 readers: read a text in accordance with their reading goals, pay attention to key points, read the text again if necessary, monitor and check their comprehension, recognize important information in a text, guess the meanings of unknown words, make use of text structure information, make inferences about the text, integrate ideas from different parts of the text, summarize the main ideas, and try to resolve difficulties during reading.

When it comes to some recent research supporting that reading strategy use contributes to reading comprehension, Phakiti (2003), for example, investigated the relationship of cognitive and metacognitive strategy use to English as a Foreign Language (EFL) reading achievement test performance. A group of Thai speakers of English was administered a multiple-choice reading comprehension achievement test and a cognitive-metacognitive questionnaire on how they thought during the achievement test. Quantitative analyses conducted with the data coming from the whole sample and qualitative analyses carried out with a small group of successful participants and another small group of unsuccessful ones revealed that cognitive and metacognitive strategy use had a positive impact on reading comprehension achievement test and successful readers use cognitive and metacognitive strategies relatively more than the unsuccessful readers.

Akkakoson (2013), accordingly, explored the relationship between strategic reading instruction, student learning of L2-based reading strategies and $\mathrm{L} 2$ reading achievement among Thai EFL learners. In this study, a group of learners was taught with a strategy-based approach, while another group of learners with similar features were taught with a traditional, teacher-centered approach. A paired sample t-test conducted on the pre-test and post-test results of the experimental group revealed that there was a statistically significant improvement in their L2 reading proficiency after the conscious L2-based reading strategy instruction. The control group was reported to have made no progress at all and even scored less on the post-test than the pre-test. Not surprisingly, an independent samples t-test carried out on the post-test results of the experimental group and the control group also displayed a statistically significant difference between the two groups in terms of their reading proficiency, with the effect size being large.

Akkakoson (2013) further investigated the process of learning strategies among the experimental group participants using a portfolio approach. For this purpose, the participants in the experimental group were divided into three 
proficiency groups as low, mid and high, and their portfolio entries regarding L2-based strategy use were analyzed. As a result, it was found that the highlevel learners in the experimental group were better than the low-level learners in the same group at learning to use L2-based reading strategies effectively. These findings indicate that (1) learning to use L2-based reading strategies contributes to reading proficiency unlike traditional teacher-centered approach, and (2) language proficiency plays an important role in learning to use L2based reading strategies.

Qanwal and Karim (2014), similarly, examined the correlation between reading strategy instruction and reading proficiency. For this purpose, they analyzed the extent to which teachers in Pakistan incorporate reading strategy instruction into their ESL reading classes, and evaluated their students' reading proficiency. The data were collected using a questionnaire assessing the teachers' use of different reading strategies in the classroom and a reading comprehension test, both administered to the students. Results showed that the English teachers included in the study practice a satisfactory level of reading strategy instruction, and a very strong positive correlation was found between the teachers' reading strategy instruction and the participants' reading comprehension.

Peng, Siriyothin and Lian (2014) also investigated the relationship between reading strategy use and reading achievements of Chinese EFL learners. Data were collected using a reading strategy questionnaire, consisting of cognitive strategies, metacognitive strategies, compensation strategies and social strategies, and a reading comprehension test. Findings suggest that of the four subcategories of reading strategies, cognitive strategies were reported to be used the most frequently, while metacognitive strategies were reported to be used the least frequently. Despite this, metacognitive strategies were found to be the only strategies that are able to predict reading comprehension as a result of a multiple regression analysis. Further, findings revealed a moderate positive correlation between reading strategy use and reading achievements of the participants.

In the light of the aforementioned studies, it can be stated that reading strategy use is an important factor in foreign language reading. It can also be stated that language teachers can better help their learners if they understand the learners' employment of reading strategies. Thus, the current study aims to investigate foreign language reading strategy use of intermediate level adult Turkish EFL learners. It is hoped that the findings of this study could provide insight for foreign language teachers and material designers. 


\section{METHOD}

\section{Participants}

The participants of this study were 87 Turkish first-year university students (age: 18-22) who were taking intermediate level English courses at a state university in Turkey. The participants' proficiency level had been determined as a result of a proficiency exam administered at the beginning of the semester they were taking the English courses. The university where the participants of the study were studying adopted an integrated approach to foreign language learning in which English was taught in a way in which language skills and sub-skills are interwoven and students are encouraged to learn these skills simultaneously.

\section{Instruments}

The Survey of Reading Strategies (SORS) was the main instrument of this study. It was adapted from the Metacognitive Awareness of Reading Strategy Inventory (MARSI), which was developed by Mokhtari and Reichard (2002). The adapted SORS was field-tested on a group of ESL students who were studying at two universities in the United States and the overall reliability was found to be 89 (Mokhtari \& Sheorey, 2002). The purpose of this survey was to collect information about the various strategies that students use when they read school-related academic materials in English such as reading textbooks for homework or examinations and reading journal articles. The participants answer the survey by using a Likert-type scale ranging from 1 (never) to 5 (always).

SORS was originally in English; however, it was translated into Turkish by means of the back-translation method in order to provide the participants with the survey in their native language so that they could better understand each item. SORS consists of 30 items. Thirteen of the items measure Global or Metacognitive Reading Strategies (GLOB). These strategies are intentional, carefully planned techniques that help learners monitor or manage their reading. They include such techniques as having a purpose in mind, previewing the text as to its length and organization and using typographical aids and tables and figures. Eight of the items in SORS measure Problem Solving or Cognitive Reading Strategies (PROB). These strategies are localized, focused techniques or the actions that readers take while they are working directly with the text. They include adjusting one's speed of reading when the text becomes too difficult or easy, guessing the meaning of unknown words, or rereading the text so as to better understand it. Nine of the items in SORS measure Support Reading Strategies (SUPP). As the name indicates, these strategies are support mechanisms that enable learners to comprehend the text 
better with the help of dictionaries, notes, or such techniques as underlining or highlighting textual information.

As suggested by Mokhtari and Sheorey (2002), the present study identified the following three levels of reading strategy use based on the average scores on the 5-point Likert scale: high (an average score of 3.5 or higher), moderate (an average score of 2.5 to 3.4), and low (an average score of 2.4 or lower). In the present study, the internal consistency of SORS was found to be good (Cronbach's $\alpha=.80$ ), indicating that all items in SORS were good enough to measure the same construct on the sample.

In order to support the quantitative data gathered from SORS, eight participants of the study were also interviewed. Based on the items in SORS, three open-ended questions for global reading strategies, two open-ended questions for problem-solving strategies, and four open-ended questions for support reading strategies were asked during the interviews.

\section{Data Analysis}

The data related to the three sections of SORS (Global Reading Strategies, Problem Solving Strategies, and Supplementary Reading Strategies) were analyzed using descriptive statistics (mean, standard deviation, frequencies, and percentages). In addition, participants' mean scores from the sections of SORS were compared using a one-way ANOVA with repeated measures. Once a significant difference was found across the three sections, paired samples ttests were employed to find out where the significance stemmed from.

As for the analysis of the qualitative data, tape-recorded interviews with the participants were first transcribed and then analyzed by grouping each interviewee's response according to the three sections of SORS. The interview data were used to support and discuss the quantitative findings of the present study.

\section{FINDINGS}

Table 1 below displays means and standard deviations for each sub-scale categories of SORS. As evident in the table, most participants reported using reading strategies at a moderate level $(M=3.40, S D=0.46)$. The highest mean score falls into the Problem-Solving Strategies, whereas the lowest mean score falls into the Global Reading Strategies. It can be seen that the Problem Solving Strategies is the most favored choice $(M=3.71, S D=0.57)$, followed by Global Reading Strategies $(M=3.43, S D=0.50)$ and Support Reading Strategies $(M=3.02$, $S D=0.57)$. 
Table 1. Means and Standard Deviations for Intermediate-level Adult Turkish EFL Learners' Reading Strategy Use

\begin{tabular}{cccc}
\hline Category & Mean & $\begin{array}{c}\text { Std. } \\
\text { Deviation }\end{array}$ & Level \\
\hline GLOB & 3.43 & .50 & Moderate \\
\hline PROB & 3.71 & .57 & High \\
\hline SUPP & 3.02 & .57 & Moderate \\
\hline Overall & 3.40 & .46 & Moderate \\
\hline
\end{tabular}

With the purpose of comparing the mean scores of Global Reading Strategies (GLOB), Problem Solving Strategies (PROB) and Supplementary Reading Strategies (SUPP) in order to find out whether the participants' awareness of subcategories of reading strategies significantly differ from each other, a one-way ANOVA with repeated measures was conducted. The findings indicated that there is a statistically significant difference $(F(2,85)=40.21, p<$ .001) across the three subcategories (Sphericity assumption was not met, Wilks' Lambda results are reported). To detect where the significant difference occurred, pairwise comparisons were calculated using paired samples $t$-test. The results showed that there is a statistically significant difference between GLOB, $p<.001$; between GLOB and SUPP, $p<.001$; and between PROB and SUPP, $p<001$. In sum, these findings support that intermediate-level adult Turkish EFL learners participating in the present study show high awareness of Problem Solving Strategies. Furthermore, although they seem to apply both Global Reading Strategies and Supplementary Reading Strategies moderately, they show significantly higher awareness for Global Reading Strategies than they do for Supplementary Reading Strategies.

Considering these overall means for each sub-scale as provided by SORS, high, moderate and low categories of Global Reading Strategies, Problem Solving Strategies and Supplementary Reading Strategies are presented and discussed below.

Table 2. Percentages for Global Reading Strategy Use Levels (GLOB)

\begin{tabular}{ccc}
\hline Level & $\mathrm{N}$ & $\%$ \\
\hline High & 40 & 46.0 \\
\hline Moderate & 44 & 50.6 \\
\hline Low & 3 & 3.4 \\
\hline
\end{tabular}

First of all, the data given in Table 2 above shows the moderate usage of the designation of global reading strategies being the most prominent with 50.6 
percent of the respondents showing their awareness in various techniques. A total of 44 students fall under the moderate usage designation of global reading strategies, whereas only three participants, corresponding to 3.4 percent of the total respondents, show the lack of awareness of such techniques. The high mean score, as suggested by SORS, made up of 3.5 and higher, also sees a high percentage, namely 46 percent, with a total of 40 respondents being in this category. This shows that almost all of the participants are able to monitor and manage their reading either moderately or very well. In other words, they have a purpose in mind when they read, preview the text, think about their previous knowledge and the content of the text, make use of visuals, typographical features, and context clues and make guesses about the text and check those guesses and their understanding. In sum, we can conclude that a good number of intermediate-level adult Turkish EFL learners participating in the present study show at least moderate awareness of Global Reading Strategies. Table 3 below displays a detailed analysis of each item of Global Reading Strategies.

Table 3. Percentages Related to the Use of Global Reading Strategies (GLOB)

\begin{tabular}{|c|c|c|c|c|c|c|c|}
\hline Item No & Item & & 1 & 2 & 3 & 4 & 5 \\
\hline \multirow[t]{2}{*}{1} & I have a purpose in mind when I read. & $\mathrm{n}$ & 2 & 6 & 28 & 34 & 17 \\
\hline & & $\%$ & 2.3 & 6.9 & 32.2 & 39.1 & 19.5 \\
\hline \multirow[t]{2}{*}{3} & $\begin{array}{l}\text { I think about what I know to help me } \\
\text { understand what I read. }\end{array}$ & $\mathrm{n}$ & 1 & 13 & 26 & 30 & 17 \\
\hline & & $\%$ & 1.1 & 14.9 & 29.9 & 34.5 & 19.5 \\
\hline \multirow[t]{2}{*}{4} & $\begin{array}{l}\text { I take an overall view of the text to see } \\
\text { what it is about before I read it. }\end{array}$ & $\mathrm{n}$ & 6 & 15 & 16 & 34 & 16 \\
\hline & & $\%$ & 6.9 & 17.2 & 18.4 & 39.1 & 16.4 \\
\hline \multirow[t]{2}{*}{6} & $\begin{array}{l}\text { I think about whether the content of the } \\
\text { text fits my reading purpose. }\end{array}$ & $\mathrm{n}$ & 8 & 9 & 27 & 33 & 10 \\
\hline & & $\%$ & 9.2 & 10.3 & 31.0 & 37.9 & 11.5 \\
\hline \multirow[t]{2}{*}{8} & $\begin{array}{l}\text { I review the text first by noting its } \\
\text { characteristics like length and } \\
\text { organization. }\end{array}$ & $\mathrm{n}$ & 31 & 26 & 19 & 8 & 3 \\
\hline & & $\%$ & 35.6 & 29.9 & 21.8 & 9.2 & 3.4 \\
\hline \multirow[t]{2}{*}{12} & $\begin{array}{l}\text { When reading, I decide what to read } \\
\text { closely and what to ignore. }\end{array}$ & $\mathrm{n}$ & 3 & 5 & 29 & 38 & 12 \\
\hline & & $\%$ & 3.4 & 5.7 & 33.3 & 43.7 & 13.8 \\
\hline \multirow[t]{2}{*}{15} & $\begin{array}{l}\text { I use tables, figures, and pictures in the } \\
\text { text to increase my understanding. }\end{array}$ & $\mathrm{n}$ & 0 & 5 & 26 & 34 & 22 \\
\hline & & $\%$ & 0 & 5.7 & 29.9 & 39.1 & 25.3 \\
\hline \multirow[t]{2}{*}{17} & $\begin{array}{l}\text { I use context clues to help me better } \\
\text { understand what I am reading. }\end{array}$ & $\mathrm{n}$ & 2 & 8 & 22 & 44 & 11 \\
\hline & & $\%$ & 2.3 & 9.2 & 25.3 & 50.6 & 12.6 \\
\hline
\end{tabular}

Journal on English as a Foreign Language, 7(2), 135-158

Copyright (C) 2017 by JEFL, p-ISSN 2088-1657; e-ISSN 2502-6615 


\begin{tabular}{|c|c|c|c|c|c|c|c|}
\hline 20 & $\begin{array}{l}\text { I use typographical features like bold } \\
\text { face and italics to identify key } \\
\text { information. }\end{array}$ & $\mathrm{n}$ & 9 & 14 & 14 & 31 & 19 \\
\hline & & $\%$ & 10.3 & 16.1 & 16.1 & 35.6 & 21.8 \\
\hline \multirow[t]{2}{*}{21} & $\begin{array}{l}\text { I critically analyze and evaluate the } \\
\text { information presented in the text. }\end{array}$ & $\mathrm{n}$ & 7 & 20 & 25 & 24 & 11 \\
\hline & & $\%$ & 8.0 & 23.0 & 28.7 & 27.6 & 12.6 \\
\hline \multirow[t]{2}{*}{23} & $\begin{array}{l}\text { I check my understanding when I come } \\
\text { across new information. }\end{array}$ & $\mathrm{n}$ & 3 & 6 & 23 & 37 & 18 \\
\hline & & $\%$ & 3.4 & 6.9 & 26.4 & 42.5 & 20.7 \\
\hline \multirow[t]{2}{*}{24} & $\begin{array}{l}\text { I try to guess what the content of the text } \\
\text { is about when I read. }\end{array}$ & $\mathrm{n}$ & 1 & 6 & 23 & 26 & 31 \\
\hline & & $\%$ & 1.1 & 6.9 & 26.4 & 29.9 & 35.6 \\
\hline \multirow[t]{2}{*}{27} & $\begin{array}{l}\text { I check to see if my guesses about the } \\
\text { text are right or wrong. }\end{array}$ & $\mathrm{n}$ & 5 & 8 & 39 & 25 & 10 \\
\hline & & $\%$ & 5.7 & 9.2 & 44.8 & 28.7 & 11.5 \\
\hline
\end{tabular}

Table 3 above indicates that for most of the items $(1,3,4,6,8,12,15,17$, 20 and 23), the participants most frequently chose 4 , which means that they usually apply these strategies. For the items 21 and 27, the most frequent response is 3 (sometimes) followed by 4 (usually). For the item 24, which is about guessing the content of the text, the most frequent response of the participants is 5, meaning always or almost always. This item-wise analysis also supports that intermediate-level adult Turkish EFL learners participating in the present study are aware of and apply some of Global Reading Strategies.

As stated earlier, semi-structured interviews focusing on reading strategies were conducted with a group of eight participants. There were four open-ended questions covering the global reading strategies:

1. Do you get prepared before reading such as taking an overall view of the text, noting its characteristics like its length and organization or thinking about your previous knowledge about the text?

2. While reading, do you use tables, figures, pictures, context clues, typographical features like bold face and italics?

3. Before and during reading, do you make guesses about the content of the text and check them later?

The participants reported not doing much preparation before reading. They stated they start reading right away without taking notes or noting the text's characteristics like its length and organization, except one participant who said: 
I do not get prepared before reading, but I try to have an overall idea of the text. I check how long it is and how many paragraphs there are.

In addition to this, another participant said:

I did not use to get prepared before reading, but I took this habit at prep school (while taking intensive English lesson at the first year of university). I feel more comfortable when I look over the reading text. It is useful.

Almost all of the interviewees reported taking a look at the title of a reading passage because the title might give insights into the content of the text. The following are some examples:

I look at the title because it reveals some information about the reading text. Then, I keep reading. As I read, connections come out.

I look at the title. The title enables us to have an overall idea about the reading text. Our teachers used to ask us about the content of the reading text; therefore, I got used to guessing the content through the title.

I just look at the title. The title may help us make guesses about the content of the reading text. If I know the content, it is easier for me to read and understand. It is useful.

Almost all of the participants reported looking at tables, figures, pictures, context clues, typographical features like bold face and italics and using them when necessary. They stated that figures, pictures, context clues, typographical features like bold face and italics might provide them visual guidance when they have difficulty in understanding something in the reading text. The participants also reported paying utmost attention to vocabulary before they start reading the text. The following are some examples:

I glance at the bold-faced and italicized parts, too. I look up their meanings and for sure take notes under them.

I check if there are unknown words. If there are any, I try to guess their meanings from the context. Except exams, I look up for the meanings of these words and take some notes.

I try to guess the meanings of the unknown words from the context. I have a look at the previous sentences. Sometimes I understand, sometimes I fail. I can guess the meanings of easy words from the sentences they are embedded. 'Easy' refers to how long the word is and 
the affixes it takes. While reading, I pay attention to bold-faced or italicized words. A noun may have been used as a verb in a text, for example.

Table 4. Percentages for Problem Solving Strategy Use Levels (PROB)

\begin{tabular}{ccc}
\hline Level & $\mathrm{N}$ & $\%$ \\
\hline High & 62 & 71.3 \\
\hline Moderate & 23 & 26.4 \\
\hline Low & 2 & 2.3 \\
\hline
\end{tabular}

When it comes to Problem Solving Strategies, according to Table 4 above, 71.3 percent of the participants fall into the high category with a total of 62 respondents. This indicates that these respondents report a high level of awareness in applying some of the Problem Solving Strategies. For example, they try to get back on track when they lose concentration, adjust their reading speed, read carefully or reread when they find the text difficult and guess the meanings of unknown words or phrases. 23 participants, corresponding to 26.4 percent of all of the respondents, do indicate that they moderately apply some of these strategies, while only 2 participants, making up 2.3 percent of the whole sample, show low awareness of Problem Solving Strategies. All in all, majority of the intermediate-level adult Turkish EFL learners participating in the present study seem to show high awareness of Problem Solving Strategies. Table 5 below displays a detailed analysis of each item of Problem Solving Strategies.

Table 5. Percentages Related to the Use of Problem Solving Strategies (PROB)

\begin{tabular}{|c|c|c|c|c|c|c|c|}
\hline $\begin{array}{c}\text { Item } \\
\text { No }\end{array}$ & Item & & 1 & 2 & 3 & 4 & 5 \\
\hline \multirow[t]{2}{*}{7} & $\begin{array}{l}\text { I read slowly and carefully to make } \\
\text { sure I understand what I am reading. }\end{array}$ & $\mathrm{n}$ & 2 & 7 & 32 & 25 & 21 \\
\hline & & $\%$ & 2.3 & 8.0 & 36.8 & 28.7 & 24.1 \\
\hline \multirow[t]{2}{*}{9} & $\begin{array}{l}\text { I try to get back on track when I lose } \\
\text { concentration. }\end{array}$ & $\mathrm{n}$ & 2 & 2 & 10 & 48 & 25 \\
\hline & & $\%$ & 2.3 & 2.3 & 11.5 & 55.2 & 28.7 \\
\hline \multirow[t]{2}{*}{11} & $\begin{array}{l}\text { I adjust my reading speed according to } \\
\text { what I am reading. }\end{array}$ & $\mathrm{n}$ & 4 & 6 & 28 & 34 & 14 \\
\hline & & $\%$ & 4.6 & 6.9 & 32.2 & 39.1 & 16.1 \\
\hline \multirow[t]{2}{*}{14} & $\begin{array}{l}\text { When text becomes difficult, I pay } \\
\text { close attention to what I am reading. }\end{array}$ & $\mathrm{n}$ & 4 & 4 & 20 & 38 & 21 \\
\hline & & $\%$ & 4.6 & 4.6 & 23.0 & 43.7 & 24.1 \\
\hline 16 & I stop from time to time and think & $\mathrm{n}$ & 5 & 11 & 27 & 26 & 18 \\
\hline
\end{tabular}




\begin{tabular}{llcccccc}
\hline \multicolumn{2}{c}{ about what I am reading. } & $\%$ & 5.7 & 12.6 & 31.0 & 29.9 & 20.7 \\
\hline 19 & $\begin{array}{l}\text { I try to picture or visualize information } \\
\text { to help remember what I read. }\end{array}$ & $\mathrm{n}$ & 2 & 4 & 23 & 35 & 23 \\
& & $\%$ & 2.3 & 4.6 & 26.4 & 40.2 & 26.4 \\
\hline 25 & $\begin{array}{l}\text { When text becomes difficult, I reread it } \\
\text { to increase my understanding. }\end{array}$ & $\mathrm{n}$ & 4 & 9 & 18 & 35 & 21 \\
\hline \multirow{2}{*}{28} & $\begin{array}{l}\text { When I read, I guess the meaning of } \\
\text { unknown words or phrases. }\end{array}$ & $\mathrm{n}$ & 3 & 9 & 21 & 38 & 16 \\
\hline & & $\%$ & 3.4 & 10.3 & 24.1 & 43.7 & 18.4 \\
\hline
\end{tabular}

According to Table 5 above, for all of the items except 7, the most frequent response was 4, which means that the participants usually apply these strategies. For item 7 , the most frequent response is 3 (sometimes) followed by 4 (usually). For these items, the most frequent response is generally followed by 5, which means that the participants always or almost always apply these strategies. This item-wise analysis also supports that intermediate-level adult Turkish EFL learners participating in the present study are well aware of and apply some of Problem Solving Strategies to an acceptable extent.

The open-ended interview questions covering problem-solving strategies are as follows:

1. What do you do to better understand/remember a reading text?

2. What do you do when you encounter with unknown words or phrases while reading a text?

With regard to the first question above, which is about better understanding and remembering a reading text, most of the participants focused on vocabulary knowledge. As exemplified below, we can understand that intermediate-level Turkish EFL learners first try to deal with unknown vocabulary when they want to achieve the goal of reading comprehension. They also report taking notes while reading to remember what they read.

If I have to read and comprehend a text, first I read and look up for the meanings of the unknown words. I check if they have different meanings. I think vocabulary knowledge is very important. I always have a vocabulary notebook. I write new words there. When I just look at those words, I remember what I read. 
To read, better understand and remember a text, I read over and over again, and take notes. I may write short summaries or tips about what I read. I look up for the meanings of the unknown words.

To better understand and remember a reading text in English, I underline the words whose meanings I do not know or consider as important. I look up for the meanings from a dictionary. I take short notes to remember what I read.

I read aloud to better understand a reading text. I use colorful pencils to underline certain parts. I write the unknown words on colorful pieces of paper and hang them above my desk. I write only the words themselves, not their meanings.

To better understand and remember what I read, first I look through it. I check the vocabulary and then I read in detail. While reading, I take short notes either in English or Turkish.

With regard to the second question above, which is about how to deal with unknown vocabulary encountered in a reading text, two of the participants report turning to the intra-word structure to guess the meaning of the unknown words as exemplified below.

If there are unknown vocabulary items, first I try to guess their meanings from the context. If I can't, I look up my dictionary. If it has a suffix, for instance, I try to understand how it changes the meaning. If I have seen the root before in another word, I think about it.

If there are unknown words, I look at their roots. If I can't understand the meaning from the root, I try to guess its meaning from the context. If I have seen the same root before in another word, I may think about the similarity between the two words. I also look at the suffixes. First, I check the sentence, then the whole text. If I fail to make a guess, I look up my dictionary.

Table 6. Percentages for Supplementary Reading Strategy Use Levels (SUPP)

\begin{tabular}{ccc}
\hline Level & $\mathrm{N}$ & $\%$ \\
\hline High & 19 & 21.8 \\
\hline Moderate & 55 & 63.2 \\
\hline Low & 13 & 15.0 \\
\hline
\end{tabular}


Finally, as for Supplementary Reading Strategies, Table 6 above indicates that moderate usage of Supplementary Reading Strategies is the most prominent with 55 participants being in this category, corresponding to 63.2 percent of the whole sample. A total of 19 participants, making up 21.8 percent of all of the respondents, fall under the high category, whereas 13 participants, forming the 15 percent of the whole sample, take place in the low category. Apparently, the majority of the participants, 85 percent of all of the respondents being in the high and moderate categories, report applying some of the Supplementary Reading Strategies. For instance, they take notes, underline or circle some information in the text, use reference materials such as a dictionary, paraphrase what they read, ask themselves questions about the text and go back and forth in the text to find relationships among the ideas in the text. Only a small group of the respondents, however, show the lack of awareness of Supplementary Reading Strategies. Therefore, we can arrive at the conclusion that most of the intermediate-level adult Turkish EFL learners participating in the present study show moderate awareness of Supplementary Reading Strategies. Table 7 below displays a detailed analysis of each item of Supplementary Reading Strategies.

Table 7. Percentages Related to the Use of Supplementary Reading Strategies (SUPP)

\begin{tabular}{|c|c|c|c|c|c|c|c|}
\hline $\begin{array}{l}\text { Item } \\
\text { No }\end{array}$ & Item & & 1 & 2 & 3 & 4 & 5 \\
\hline \multirow[t]{2}{*}{2} & $\begin{array}{l}\text { I take notes while reading to help me } \\
\text { understand what I read. }\end{array}$ & $\mathrm{n}$ & 30 & 18 & 23 & 10 & 6 \\
\hline & & $\%$ & 34.5 & 20.7 & 26.4 & 11.5 & 6.9 \\
\hline \multirow[t]{2}{*}{5} & $\begin{array}{l}\text { When text becomes difficult, I read } \\
\text { aloud to help me understand what I } \\
\text { read. }\end{array}$ & $\mathrm{n}$ & 34 & 21 & 17 & 10 & 5 \\
\hline & & $\%$ & 39.1 & 24.1 & 19.5 & 11.5 & 5.7 \\
\hline \multirow[t]{2}{*}{10} & $\begin{array}{l}\text { I underline or circle information in the } \\
\text { text to help me remember it. }\end{array}$ & $\mathrm{n}$ & 13 & 16 & 15 & 22 & 21 \\
\hline & & $\%$ & 14.9 & 18.4 & 17.2 & 25.3 & 24.1 \\
\hline \multirow[t]{2}{*}{13} & $\begin{array}{l}\text { I use reference materials (e.g., a } \\
\text { dictionary) to help me understand } \\
\text { when I read. }\end{array}$ & $\mathrm{n}$ & 10 & 17 & 19 & 23 & 17 \\
\hline & & $\%$ & 11.5 & 19.5 & 21.8 & 26.4 & 19.5 \\
\hline \multirow[t]{2}{*}{18} & $\begin{array}{l}\text { I paraphrase (restate ideas in my own } \\
\text { words) of better understand what I } \\
\text { read. }\end{array}$ & $\mathrm{n}$ & 12 & 21 & 18 & 20 & 16 \\
\hline & & $\%$ & 13.8 & 24.1 & 20.7 & 23.0 & 18.4 \\
\hline 22 & I go back and forth in the text to find & $\mathrm{n}$ & 7 & 13 & 25 & 29 & 13 \\
\hline
\end{tabular}




\begin{tabular}{|c|c|c|c|c|c|c|c|}
\hline & relationships among ideas in it. & & & & & & \\
\hline & & $\%$ & 8.0 & 14.9 & 28.7 & 33.3 & 14.9 \\
\hline \multirow[t]{2}{*}{26} & $\begin{array}{l}\text { I ask myself questions I like to have } \\
\text { answered in the text. }\end{array}$ & $\mathrm{n}$ & 21 & 19 & 27 & 15 & 5 \\
\hline & & $\%$ & 24.1 & 21.8 & 31.0 & 17.2 & 5.7 \\
\hline \multirow[t]{2}{*}{29} & $\begin{array}{l}\text { When reading I translate from English } \\
\text { into my native language. }\end{array}$ & $\mathrm{n}$ & 6 & 10 & 25 & 23 & 23 \\
\hline & & $\%$ & 6.9 & 11.5 & 28.7 & 26.4 & 26.4 \\
\hline \multirow[t]{2}{*}{30} & $\begin{array}{l}\text { When reading I think about } \\
\text { information in both English and my } \\
\text { mother tongue. }\end{array}$ & $\mathrm{n}$ & 1 & 9 & 26 & 31 & 20 \\
\hline & & $\%$ & 1.1 & 10.3 & 29.9 & 35.6 & 23.0 \\
\hline
\end{tabular}

Table 7 above clearly displays that the participants' responses vary more in Supplementary Reading Strategies than in the previous two sub-categories. For the items 2 and 5 , the most frequent response is 1 , which means that most of the participants in the present study never or almost never take notes while reading or read aloud. For the item 18, which is about paraphrasing to understand the text better, the percentages of each option are quite close to each other, with 2 (occasionally) and 4 (usually) being the most frequent ones. For the rest of the items $(10,13,22,26,29$ and 30) the most frequent responses are 4 (usually) and 3 (sometimes), indicating that most of the intermediate-level adult Turkish EFL learners participating in the present study apply some of the Supplementary Reading Strategies moderately.

The open-ended interview questions covering supplementary reading strategies are as follows:

1. While reading a text, do you take notes, underline or circle certain information?

2. Do you use a dictionary while reading a text? Bilingual or monolingual?

3. While reading a text in English, do you translate the information into Turkish?

4. What do you do if the text is too difficult for you? (Refers to problemsolving strategies as well.)

As the participants' responses reveal, Turkish EFL learners are not much used to taking notes either before or during reading. They take notes mainly for unknown vocabulary. Similarly, they underline or circle unknown vocabulary rather than textual information. Once again, vocabulary knowledge seems to be a priority in reading a text in English for Turkish EFL learners. 
With regard to the dictionary use, most participants reported using bilingual dictionaries because they find it easier. However, it is worth mentioning that they are aware of the fact that using monolingual dictionaries is more advantageous for learning a language as exemplified below.

I use a bilingual dictionary because it is easier. I want to find the meaning right away. I know I shouldn't because a language may not be translated into another one exactly, but I do. If I use an English monolingual dictionary, I get the meaning more clearly and my English improves. Despite this, I use a bilingual dictionary.

I use a bilingual dictionary. I used to use an English monolingual dictionary, but I did have difficulty in understanding and started using a bilingual dictionary. It is easier to understand but it may have disadvantages. For example, I cannot learn the synonyms from a bilingual dictionary. Moreover, knowing only the Turkish equivalent of the words is not enough to be successful in the classroom, in a quiz or in an exam. However, it is easier to learn Turkish equivalents of the unknown words.

I use a bilingual dictionary. When there are unknown words, I look up a dictionary right away and I do not forget their meanings. If I use an English monolingual dictionary, there might be unknown words in its definition as well and I do not understand them, either. However, I am likely to learn new words from an English bilingual dictionary and I can see how a word is used.

I use a bilingual dictionary. I take the easy way out but it doesn't work; I do not understand how the word is used. I can learn how a word is used and its part of speech from an English monolingual dictionary. The reason why I use a bilingual dictionary is that it is a habit. An English monolingual dictionary is more advantageous because I can learn how words are used and every single word in English does not have to have a Turkish equivalent.

Most of the interviewees reported translating the information into Turkish while they are reading. One participant stated that she translates the information into Turkish although she knows that this is not good for her English proficiency development. Another participant reported that she learned to try comprehending the overall text in English without translating the information into Turkish at the English preparatory school. 
When it comes to the last open-ended question in this part regarding what the participants do when the text is too difficult for them, they reported using such reference materials as dictionaries, grammar books and asking help from a friend or family member. Almost all of the participants stated that unknown vocabulary makes a reading text difficult; therefore, it is first necessary to deal with unknown vocabulary. To do this, they mentioned reading books in English -although they report not doing so- and watching movies and TV series with English subtitles. Some of the participants stated that grammatically complex sentences also make a reading text difficult; however, they reported that vocabulary knowledge plays a far more important role in comprehending a reading text in a foreign language.

The overall findings gathered from the semi-structured interviews support that the participants in the present study use reading strategies moderately. They seem to be aware of most of these strategies, but they are either not used to applying them or keep away from doing so. Moreover, they pay utmost attention to vocabulary knowledge while they are reading in English. They think that the more unknown vocabulary in a reading text, the less comprehension.

\section{DISCUSSION}

The present study revealed that intermediate-level adult Turkish EFL learners show the moderate overall use of reading strategies. This finding concerning moderate overall use of reading strategies is compatible with the findings of Sheorey and Mokhtari (2001), who administered the SORS to a group of ESL learners coming from different L1 backgrounds along with a group of native speakers of English, and Aziz et al. (2011), in which sixty Malay learners of English responded the same survey. On the other hand, the present study slightly differs from Chumworatayee (2012), who used SORS to measure the students' metacognitive awareness of reading strategies while reading academic materials, in the sense that there is a minor difference between the overall score average of the reading strategies in the present study $(\mathrm{M}=3.40$, Moderate overall use of reading strategies) and the Chumworatayee's (2012) study ( $\mathrm{M}=3.54$, High overall use of reading strategies).

Another finding of the present study with regard to reading strategy use is that problem-solving strategies are the most favored strategies by intermediate-level adult Turkish EFL learners and they are followed by global reading strategies and supplementary reading strategies. This finding is in line with Aziz et al. (2011) and Chumworatayee (2012), who also reported that Malay EFL learners and Thai EFL learners respectively used problem-solving strategies more often than global reading strategies and than supplementary 
reading strategies. However, the present study differs from Sheorey and Mokhtari (2001) and Tercanlığlu (2004), who stated that EFL/ESL learners employ global reading strategies more often than problem-solving strategies. Support reading strategies are the least preferred ones among EFL/ESL learners as most studies state. However, with regard to support reading strategies, it is worth mentioning that studies comparing native speakers of English and ESL/EFL learners in terms of reading strategy use, point out that ESL/EFL learners resort to supplementary reading strategies more often than native speakers do (Tercanlıoğlu, 2004).

The results of the present study also revealed that intermediate-level adult Turkish EFL learners reported using a wide array of reading strategies to achieve reading comprehension. The participants showed an overall moderate to high awareness of reading strategies. One possible explanation for the moderate to high awareness of reading strategies among intermediate-level adult Turkish EFL learners might lie in their proficiency level and thus high motivation to be successful in English. Sheorey and Mokhtari (2001) and Tercanlığlu (2004) note that like native readers, proficient EFL/ESL readers are well aware of reading strategies and able to monitor these strategies reasonably while reading academic texts. Therefore, the moderate to high awareness of reading strategies among intermediate-level adult Turkish EFL learners is not surprising.

When it comes to the reason why the participants in the present study reported using problem-solving strategies more often than global reading strategies, it is necessary to consider the characteristics of these categories of reading strategies. As Mokhtari and Sheorey (2002) point out, problem-solving strategies are cognitive strategies and they are localized, focused techniques that readers turn to when they have a problem while reading. Considering that the participants in the present study are learning English as a foreign language and they do not have much chance to be engaged in English outside the classroom, it is quite likely for them to have problems while they are reading academic texts. Besides, they have to comprehend these texts as it is mostly an academic requirement, which means that they need to overcome any problem they face to be able to better understand these texts. Global reading strategies, on the other hand, are intentional and carefully planned metacognitive strategies. These strategies imply monitoring one's own reading, which requires more proficiency in the language. Therefore, it is expected that Turkish students learning English as a foreign language use global reading strategies less frequently than problem-solving strategies. As for supplementary reading strategies, lastly, they serve to aid the reader in comprehending the text. In this sense, we expect EFL learners to use these strategies more frequently. The 
reason why they use these strategies less frequently than expected might lie in that they are not used to taking these actions such as taking notes while reading, underlining or circling textual information, using dictionaries or paraphrasing.

\section{CONCLUSION}

The current study, in which a total of 87 intermediate-level adult Turkish EFL learners were administered the Survey of Reading Strategies, revealed that intermediate-level adult Turkish EFL learners show the moderate overall use of reading strategies. Additionally, it was found that problem-solving strategies are the most favored strategies among intermediate-level adult Turkish EFL learners, and they are followed by global reading strategies and supplementary reading strategies. The overall findings gathered from the semi-structured interviews also supported that the participants in the present study use reading strategies moderately. It is worth noting that it might be necessary to increase reading strategy use among intermediate-level adult Turkish EFL learners considering that the strong positive correlation between reading strategy use and $\mathrm{L} 2$ reading comprehension that the previous literature revealed.

\section{REFERENCES}

Akkakoson, S. (2013). The relationship between strategic reading instruction, student learning of L2-based reading strategies and L2 reading achievement. Journal of Research in Reading, 36(4), 422-450.

Aziz, N. A., Ab Rahim, S., Harun, E. H. B., Adzmi, N. A., Ahmat, H., Bidin, S., \& Shaharudin, M. R. (2011). The reading strategies awareness among English as a second language (ESL) learners in Malaysia's university. Theory and Practice in Language Studies, 1(7), 778-784.

Block, C., \& Pressley, M. (2007). Best practices in teaching comprehension. In L. Gambrell, L. Morrow and M. Pressley (Eds.), Best Practices in Literary Instruction (3rd ed., pp. 220-242). New York: Guilford Press.

Chumworatayee, T. (2012). Thai adult EFL learners' metacognitive awareness of reading strategies. The International Journal of Interdisciplinary Social Sciences, 6(9), 83-95.

Grabe, W. (2009). Reading in a second language: Moving from theory to practice. New York (NY): Cambridge University Press.

Grabe, W., \& Stoller, F. L. (2002). Teaching and researching reading. Great Britain: Pearson Education Limited.

Guthrie, J., \& Taoada, A. (2004). Fostering the cognitive strategies of reading comprehension. In J. Guthrie, A. Wigfield, \& K. Perencevich (Eds.), 
Motivating Reading Comprehension: Concept-oriented Reading Instruction (pp. 87-112). Mahwah, NJ: L. Erlbaum.

Hedge, T. (2000). Teaching and learning in the language classroom. Oxford: Oxford University Press.

Hudson, T. (2007). Teaching second language reading. New York: Oxford University Press.

Jeon, E. H., \& Yamashita, J. (2014). L2 reading comprehension and its correlates: A meta-analysis. Language Learning, 64(1), 160-212.

Koda, K. (2000). Cross-linguistic variations in L2 morphological awareness. Applied Psycholinguistics, 25, 297-320.

Koda, K. (2005). Insights into second language reading: A cross-linguistic approach. Cambridge: Cambridge University Press.

Mokhtari, K., \& Reichard, C. A. (2002). Assessing students' metacognitive awareness of reading strategies. Journal of Educational Psychology, 94 (2), 249-259.

Mokhtari, K., \& Sheory, R. (2002). Measuring ESL students' awareness of reading strategies. Journal of Developmental Education, 25(3), 2-10.

Nassaji, H. (2003). Higher-level and lower-level text processing skills in advanced ESL Reading comprehension. The Modern Language Journal, 87(2), 261-276.

Paris, S. G., Wasik, B. A., \& Turner, J. C. (1991). The development of strategic readers. In R. Barr, M.L. Kamil, P. Mosenthal, \& P.D. Pearson (Eds.), Handbook of Reading Research (pp. 609-640). White Plains, NY: Longman.

Peng, S., Siriyothin, P., \& Lian, A. P. (2014). Reading strategy use and reading proficiency of Chinese undergraduate students majoring in English. International Journal of Academic Research, 6 (2), 69-74.

Phakiti, A. (2003). A closer look at the relationship of cognitive and metacognitive strategy use to EFL reading achievement test performance. Language Testing, 20(1), 26-56.

Pressley, M., \& Wharton-McDonald, R. (1997). Skilled comprehension and its development through instruction. School Psychology Review, 26, 448-466.

Qanwal, Karim, \& Karim, S. (2014). Identifying correlation between reading strategies instruction and L2 text comprehension. Journal of Language Teaching and Research, 5(5), 1019-1032.

Rice, M. (2009). Research-based reading instruction: reading comprehension skills and strategies. Florida Center for Reading Research: Making Connections. Educators Publishing Service. Retrieved from https://eps.schoolspecialty.com 
Sheorey, R., \& Mokhtari, K. (2001). Differences in the metacognitive awareness of reading strategies among native and non-native readers. System, 29(4), 431-449.

Tercanlionglu, L. (2004). Postgraduate students' use of reading strategies in L1 and ESL contexts: Links to success. International Education Journal, 5(4), 562-570.

Zhang, Z. (1993). Literature review on reading strategy research. A paper presented at the Annual Meeting of the Mid-South Educational Research Association. New Orleans, LA.

\section{Authors' Brief CV}

Fatma Aydin is an EFL lecturer at Anadolu University, School of Foreign Languages in Eskisehir, Turkey. She holds an MA degree in Teaching English as a Foreign Language. Her research interests include reading in a foreign language, foreign language reading strategies, and morphological awareness.

Ozgur Yildirim is an EFL teacher trainer at Anadolu University, Faculty of Education in Eskisehir, Turkey. He holds a Ph.D. degree on Second and Foreign Language Education. His research interests include learner autonomy in second and foreign language education, EFL teacher training, strategy use in foreign language learning, and international education. 
